\title{
EARNINGS AND CASH FLOW PERSISTENCE - CASE OF MEDIUM AGRICULTURE ENTERPRISES IN SERBIA
}

\author{
Slavica Stevanovićl, Jelena Minovićn ${ }^{2}$ Grozdana Marinković3 \\ *Corresponding authorE-mail: slavica.stevanovic@ien.bg.ac.rs
}

\begin{abstract}
A R T I C LE IN F O
A B S T R A C T

Original Article

Received: 10 December 2020

Accepted: 29 December 2020

doi:10.5937/ekoPolj2101141S

UDC 331.28:631.164.6(497.11)

This paper examines the earnings and cash flow persistence of selected agriculture Serbian enterprises as a measure of their earnings quality. We study the persistence of income statements and cash flow statement items of medium-sized agriculture enterprises in Serbia. Agriculture is a relevant sector for the national economy and medium-sized enterprises are the main drivers of her economic growth.

Keywords:

persistence, earnings quality, agriculture. medium-sized enterprises, Serbia

JEL: M20, L25, Q19

We use panel regression analysis with annual data over the period from 2010 to 2018 . The results of our research indicate that earnings and cash flow-based indicators have different persistence. Analysing accruals and net cash flows of operating activities as determinants of operating profit of analysed enterprises, we conclude that operating profit that represents accruals are more persistent than operating profit backed by net operating cash flows.
\end{abstract}

(C) 2021 EA. All rights reserved.

\section{Introduction}

Earning generated over some period as a measure of an enterprises' success is often the most crucial goal in doing its business. The company's stakeholders see fulfilling their interests in a positive and satisfactory net financial result. Earnings information as a part of accrual-based accounting is base for making business decisions. Earning has become the most common subject of manipulation in numerous frauds and creative financial reporting. Mulford and Comiskey (2005) point out that "analysts, investors, and creditors, burned by the trust they have placed in reported earnings in an era of fraud and deceit in financial reporting, have turned their attention to cash flow as a

1 Slavica Stevanović, Research Associate, Institute of Economic Sciences, Zmaj Jovina 12, Belgrade, Serbia, Phone: +381 638729 970, E-mail: slavica.stevanovic@ien.bg.ac.rs, ORCID ID (https://orcid.org/0000-0002-8545-4540)

2 Jelena Minović, Senior Research Associate, Institute of Economic Sciences, Zmaj Jovina 12, Belgrade, Serbia, Phone: +381 698893 301, E-mail: jelena.minovic@ien.bg.ac.rs, ORCID ID (https://orcid.org/0000-0001-6254-4888)

3 Grozdana Marinković, Associate Professor, Belgrade Banking Academy, Zmaj Jovina 12, Belgrade, Serbia, Phone: +381 642668 546, E-mail: grozdana.marinkovic@bba.edu.rs, ORCID ID (https://orcid.org/0000-0002-9425-4479) 
directional beacon guiding them through the uncharted and risky waters of modern financial analysis". Some managers use aggressive accounting or fraud to avoid reporting a decline in earnings (Dechow and Schrand, 2004). Intentionally trying to hide current good performance and presenting earnings lower than realized, the company's management wants to defer payment of income tax or defer part of the profit to future accounting periods.

Earnings persistence is earnings quality measures commonly used in the empirical literature. The aim of our paper is to assess the earnings persistence and cash flow persistence of selected Serbian enterprises using the panel autoregression and regression model with annual data that cover the period from 2010 to 2018 . The research results indicate that operating profit is more persistent than net profit and cash flow-based indicators of analysed agriculture enterprises. This paper contributes significantly to the existing literature of earnings quality and can be of interest to readers in academic areas and practitioners.

The sample includes the medium-sized agriculture enterprises in Serbia because the agriculture sector is much essential for the Serbian economy measured by the share of this sector in GDP and total employment. Medium-sized enterprises also have a significant impact on the economic performance of the national economy. According to key developing indicators, medium enterprises represent the backbone of national economies although a modest share in the overall structure of enterprises (Đuričin et al., 2018). According to the data of the Serbian Business Registers Agency - SBRA (2019), Serbian enterprises that operate in sector A - Agriculture, Forestry and Fishery are about $3.8 \%$ of the total number of enterprises. This sector employs about $2.8 \%$ of the total number of employees and generates $3 \%$ of the total revenues of all enterprises in Serbia. After several consecutive years with a positive financial performance, aggregated profit and loss statements of this sector reported a negative net result in 2018 in the amount of 1,750.2 million dinars. In 2019 agriculture sector realized a positive net result in the amount of 6,184.7 million dinars. Observing the results structure, the agriculture sector noticed positive and significant operating profit, even in 2018, when the final negative net financial result influenced by high negative results from temporary activities.

This paper consists of five sections. After the introduction as a first section, the literature review is presented in the second section. The third section explains the used data and methodology. The results and discussions are explained in the fourth section. Finally, the fifth section contains the main conclusions.

\section{Materials and methods}

\section{Theoretical Background}

Reported earnings as a measure of the company's success can be the effect of actual business transactions, but to a greater or lesser extent may be the result of the application of specific balance sheet policy measures by the company's management. 
How management uses the flexibility of the methods and policies provided by accounting regulations, as well as whether there is a violation of applicable accounting frameworks, it is crucial to determine to assess the quality of profit shown in the income statement (Stevanović and Marinković, 2017). Numerous studies that examine the earnings quality are based on the use of one or a set of quality measures. Dechow et al. (2010) in their research concluded that there is no superior measure of profit quality and point out that alternative quality measures should not be used as substitutes, but as complementary measures.

Earnings quality measurement cannot be focused on accrual-based indicators alone. The analysts have to use the cash flow statement of enterprises in earnings quality assessing process, in combination with the other financial statements, especially income statement and balance sheet. "Financial officer of Tyco International Ltd. company told investors to forget reported earnings and instead focus on cash-flow generation as a percentage of net income" to verify if earnings quality of their company is good (Mulford and Comiskey, 2005, 95). Dechow and Schrand (2004) conclude that earnings data backed by cash flows data perform better in predicting future earnings than earnings data alone. Strong and stable net operating cash flow is a sign of high-quality earnings (Stevanović et al., 2013).

The earnings quality depends on its stability, but also on the sources from which it originates. Certainly, stability, sustainable and real sources of income have a positive effect on the reality of the reported earnings. Suppose the high profitability is the result of the payment of a temporary nature, which will not appear regularly. In that case, the reported profit is not entirely of a sustainable nature. Meeampol et al. (2013) point out that "in accounting if the net income is stable and not fluctuating, it has a significantly lesser risk because the risk is positively correlated with income".

Managers often want to improve the reputation of the company that they manage with investors and the other stakeholders, and persistent earnings can help them in this. Persistence can be used as time series and accounting-based measures of earnings quality. Persistence determines the extent that current earnings persist in the future period (Perotti and Wagenhofer, 2014). Demerjian et al. (2013) select earnings persistence and the other three earnings quality measures to examine the impact of managers on accrual estimation. Pagalung and Sudibdyo (2018) include persistence as one of accounting-based earnings quality attributes in their research of earnings quality factors and the economic consequences in the Indonesian capital market. Earnings persistence as earning quality measure in their research use Dasmaran and Mulyani (2019), Nuris and Juliardi (2017), and Huq (2016).

Boulton et al. (2011) use earnings management measures as earnings quality measures defined by Leuz, Nanda and Wysocki. Their criteria include earnings smoothing measurements. Perotti and Wagenhofer (2014) also use earnings measures that reflect smoothness of earnings where smoothness measures are based on the earnings volatility, or accruals relative to the operating cash flows volatility. 
Based on the earnings quality literature over the past four decades, Srivastava (2014) point out that there has been an increase in the volatility of earnings. She also notices a decrease in the earnings relevance and a reduction in the degree of matching between concurrent revenues and expenses, that can be interpreted as an earnings quality decline. Dechow and Schrand (2004) in their research, also conclude that earnings quality has deteriorated over the past 40 years because of the increasing number of companies reporting losses and to "nonrecurring" special items.

Perotti and Wagenhofer (2014) in their research include accounting-based and marketbased earnings quality measures that are commonly used in the empirical literature. Aboody et al. (2005) use the accrual value (the discretionary component of accrual) for earnings quality defining. If the absolute value of accrual is larger, the earnings quality is lower. Milić et al. (2018) used residuals from accruals models approach to capture earnings management in Serbian agricultural companies. In the research of Pagalung and Sudibdyo (2018), the earnings quality, among other things, was measured by accrual quality. Francis et al. (2008) use absolute abnormal accruals for constructing earnings quality measure too, but also three other measures such as accruals quality, earnings variability, and a combined measure.

\section{Methodology}

We tested the persistence of selected earnings and cash flow-based indicators on the sample that includes the medium-sized agriculture enterprises. The share of agriculture sector in the GDP of Serbia is significant compared to EU countries, which is in line with the richness of natural resources, climatic conditions, but also the low level of productivity of agricultural production and the development of other activities in Serbia. We used the panel autoregression and panel regression model over the period from 2010 through 2018. It is a sample of 70 medium-sized agriculture enterprises operating in Serbia with the total number of observations being 630 .

The analysed Serbian agriculture enterprises predominant do business in eight different group of economic activities. The most significant share in the sample structure (77\%) is that of enterprises from group of activities named Growing of cereals (except rice), leguminous crops and oil seeds. Four percent enterprises operate in each of the following group of activities: Growing of other non-perennial crops; Raising of swine/pigs and Raising of poultry. Three percent enterprises of total observed agriculture enterprises do business in group of economic activities named Growing of pome fruits and stone fruits, Freshwater aquaculture and Raising of dairy cattle. One agriculture enterprise predominant operates in group activities Support activities for crop production.

The analysed variables are determined based on annual financial statements data that include balance sheet, income statement and cash flow statement data. The Register of Financial Statements of the Serbian Business Registers Agency is the source of mentioned data for each agriculture medium enterprise individually (SBRA). The annual analyses cover the period 2010-2018. The analysed enterprises are classified 
as medium-sized enterprises in 2015 based on the average number of employees, operating income, and an average value of operating assets at 31 December 2014. In 2015, 74 medium-sized enterprises did business in sector Agriculture, forestry, and fishery. There are no publicly available financial statements for four enterprises that are excluded from analyses. Two enterprises are excluded from register of Business Registers Agency, one enterprise is inactive, and one is in the bankruptcy process.

Analyse of medium enterprises in this sector by size, shows that $70 \%$ of enterprises are classified as medium enterprises in the period 2016-2018 too. In the same period, $10 \%$ of enterprises are classified as small, one percent as micro and one percent of enterprises became large-sized enterprises. Remaining enterprises (18\%) has changed size during period 2016-2018, and their size mostly was decreased.

Earnings quality measures that we used refers to earnings persistence. Persistence is one of accounting-based earnings quality attributes, and it was measured by the regression coefficient of current earnings towards future earnings (Pagalung and Sudibdyo, 2018). "Greater earnings persistence is a meaningful definition for earnings quality only if earnings truly reflect performance during the period and if current-period performance persists in future periods" (Dechow and Schrand, 2004). Earnings persistence as a timeseries measure is equal to the coefficient beta value of the regression between current period earnings and past period earnings (from the autoregressive equation of annual earnings). High persistence is positively associated with high earnings quality since it indicates a stable, sustainable, and less volatile earnings generation process (Perotti and Wagenhofer, 2014).

Autoregression that we use to assess persistence of selected earnings and cash flowbased indicators is given with the following equation:

$R_{i, t+1}=\mathrm{c}+\beta R_{i, t}+\varepsilon_{t+1} R_{i, t+1}=\mathrm{c}+\beta R_{i, t}+\varepsilon_{t+1}$

where $\mathrm{R}$ are selected earnings and cash flow-based indicators, $\mathrm{c}$ is the constant term, $\beta$ is coefficient of persistence, and $\varepsilon$ is disturbance term, $i$ is enterprise $(i=1, \ldots, 70)$, and $t$ is the period.

Panel regression that we use to estimate persistence accruals and net operating cash flows as determinants of the operating profit is given with the following equation:

$O P M_{i, t+1}=\mathrm{c}+\alpha A C C_{i, t}+\chi C F O M_{i, t}+\varepsilon_{t+1}$

where OPM is operating profit margin, ACC is accounting accruals, CFOM is cash flow operating margin, $\mathrm{c}$ is a constant term, $\alpha$ and $\gamma$ are coefficients, $\varepsilon$ is disturbance term, $i$ is enterprise $(i=1, \ldots, 70)$, and $t$ is the period.

We used seven indicators for our autoregressions and three for the panel regression model. We define earnings as operating profit and net profit, so that earnings-based indicators are operating profit margin and profit margin. Cash flow-based indicators include net cash flow operating margin, net cash flow investing margin, net cash flow financing margin, 
and free cash flow margin. Operating Profit Margin (OPM) represents the operating result (difference between operating revenues and operating costs) divided by operating revenues. Profit Margin (PM) represents the net financial results (difference between total revenues and total costs) divided by operating revenues. Accounting Accruals (ACC) represents the difference between operating results and net operating cash flow that is divided by operating revenues. Net Cash Flow Operating Margin (NCFOM) represents the net operating cash flow (difference between cash inflows from operating activities and cash outflows used by operating activities) divided by operating revenues. Net Cash Flow Investing Margin (NCFIM) represents the net investing cash flow (difference between cash outflows used in investing activities and cash inflows provided by investing activities) divided by operating revenues. Net Cash Flow Financing Margin (NCFFM) represents the difference between cash inflows provided by financing activities and cash outflows used by financing activities that is divided by operating revenues. Free Cash Flow Margin (FCFM) represents free cash flow as a difference between net operating cash flow and net capital expenditures divided by operating revenues.

\section{Results and discussions}

Earnings and cash flow-based indicators analysis are realized to assess the profitability flow and cash flow persistence of medium-sized enterprises and monitor the relationship between operating profit margin and net cash flow operating margin in 2010-2018.

Trend analysis of the operating profit margin and profit margin of selected mediumsized agriculture enterprises is realized based on the median values of the mentioned indicators. Their trend in the period 2010-2018 is shown in Figure 1.

Figure 1. Earnings-based indicators in the period 2010-2018

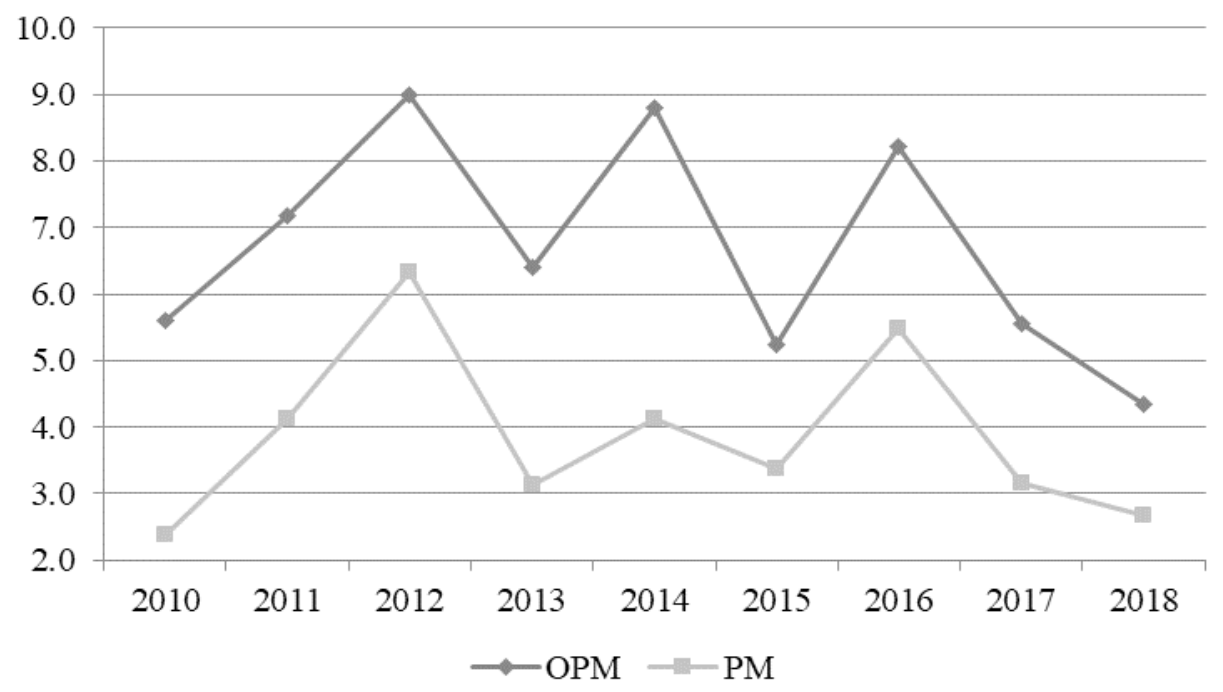

Source: Authors' calculation based on SBRA data Note: OPM- Operating Profit Margin; PM- Profit Margin 
The trend of observed earnings-based indicators in the period 2010-2018 is equal. Medium-sized agriculture enterprises notice a continuous improvement in profitability flows in 2011, 2012, 2014, and 2016, observing operating profit margin and profit margin. The highest median operating profit and median net profit were achieved in 2012, while the lowest median operating profit margin was in 2018 and the lowest median profit margins were in 2018 and 2010. The decrease of earnings-based indicators is noticed in 2013, 2015, 2017, and 2018.

Trend analysis of cash flow-based indicators (net cash flow operating margin, net cash flow investing margin, net cash flow financing margin, and free cash flow margin) of selected medium-sized agriculture enterprises is realized based on median values of the mentioned indicators. Their trend in the period 2010-2018 is shown in Figure 2.

Figure 2. Cash flow-based indicators in the period 2010-2018

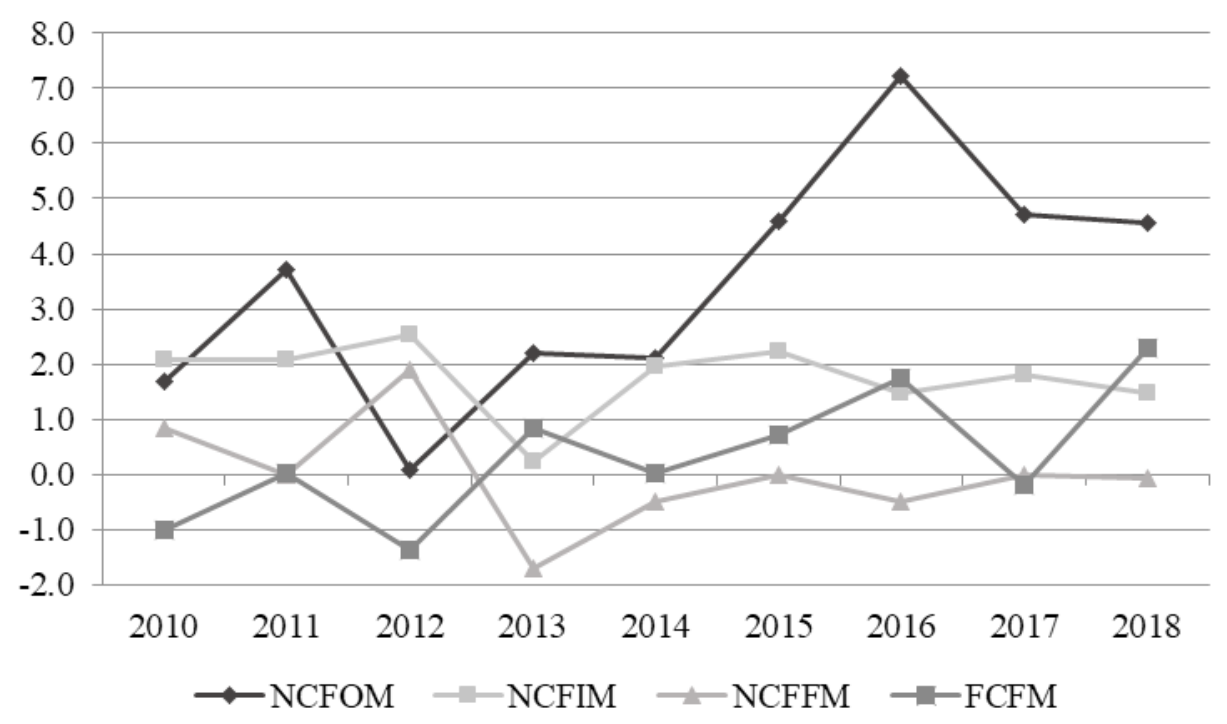

Source: Authors' calculation based on SBRA data

Note: NCFOM- Net Cash Flow Operating Margin; NCFIM- Net Cash Flow Investing Margin;

NCFFM- Net Cash Flow Financing Margin; FCFM-Free Cash Flow Margin.

The trend of observed cash flow-based indicators in the period 2010-2018 is unequal. Medium-sized agriculture enterprises noticed an increase of median net cash flow operating margin in 2011, 2013, and 2015-2016. The median free cash flow margin marks the same trend, whereby it also increased in 2018. The highest median net cash flow operating margin was noticed in 2016. but the lowest in 2012. The median net cash flow investing margin and median net cash flow financing margin have the equable trends. They increase in 2012, 2014, 2015 and in 2017. In other periods, medians of these indicators decline.

Table 1 shows the persistence of selected earnings and cash flow-based indicators, on average, for the period 2010-2018. The operating profit and net profit data are used 
from income statements. Net cash flow from operating activities, net cash flow from investing activities, net cash flow from financing activities and free cash flow are used from cash flow statements. Accounting accruals values are included in the persistence analyse. Selected statements items are scaled by operating revenue. The total accruals can be defined as differences between net income before extraordinary items and cash flow from operations (Aboody et al., 2005) or between earnings and cash flow from operations (Demerjian et al., 2013).

Table 1. Persistence of earnings and cash flow-based indicators

\begin{tabular}{|c|c|c|}
\hline \multirow{2}{*}{ Variable } & \multicolumn{2}{|c|}{ Persistence } \\
\hline & Beta & p-value \\
\hline Operating Profit Margin - OPM & 0.455 & 0.000 \\
\hline Profit Margin - PM & 0.374 & 0.000 \\
\hline Accounting Accruals - ACC & 0.338 & 0.000 \\
\hline Net Cash Flow Operating Margin - NCFOM & 0.055 & 0.227 \\
\hline Net Cash Flow Financing Margin - NCFIM & 0.412 & 0.000 \\
\hline Net Cash Flow Investing Margin - NCFFM & 0.026 & 0.235 \\
\hline Free Cash Flow Margin - FCFM & 0.264 & 0.000 \\
\hline
\end{tabular}

Source: Authors' calculation

Folowing autoregressions show estimated persistence parameters:

$$
\begin{aligned}
& \text {OPM }_{t+1}=0.455 \text { OPM }_{t}+\varepsilon_{t+1} \\
& P M_{t+1}=0.374 P M_{t}+\varepsilon_{t+1} \\
& \text { ACC }_{t+1}=0.338 \text { ACC }_{t}+\varepsilon_{t+1} \\
& \text { NCFOM }_{t+1}=3.383+\varepsilon_{t+1} \\
& \text { NCFIM }_{t+1}=2.629+0.412 \text { NCFIM }_{t}+\varepsilon_{t+1} \\
& \text { NCFFM }_{t+1}=\varepsilon_{t+1} \\
& \text { FCFM }_{t+1}=0.264 F C F M_{t}+\varepsilon_{t+1}
\end{aligned}
$$

The higher the regression beta coefficient of current earnings towards the future earnings shows the earnings persistence and the smaller the beta coefficient can mean the lower the earnings quality or, the higher the transitory earnings. The higher beta coefficient is closer to one, the smaller beta is closer to zero (Pagalung and Sudibdyo, 2018).

Results of persistence analysis show that if an enterprise generates an operating profit of $1.00 \mathrm{RSD}$, then, on average, $0.455 \mathrm{RSD}$ will persist into next year's operating profit. The results indicate that operating profit (0.455) is more persistent than net profit $(0.374)$, and this can result from the fact that net profit contains financial and other revenues and less persistent costs. Cash flow-based indicators have different persistence rates 
and less in comparison to operating profit persistence. Accruals values (0.338) are less persistent than operating profit and net profit but more persistent than free cash flow (0.264). Net cash flow operating margin and net cash flow financing margin are white noise processes. Betas are not statistically significant in these processes.

A stable relationship between operating profit margin and cash flow operating margin is a good assumption for the satisfactory the reported operating profit quality, the sustainability of a positive operating result and the sustainability of the net cash flow from operating activities. A different trend of operating profit margin and cash flow margin can be explained in the short run, while such a movement is unsustainable in the long run (Đuričin et al., 2019). The trend analysis of the difference between operating profit margin and cash flow operating margin for selected enterprises was conducted based on the median values of the mentioned determinants and their trend in the period 2010-2018 is shown in Figure 3.

Figure 3. The trend of Operating profit margin and Net cash flow operating margin

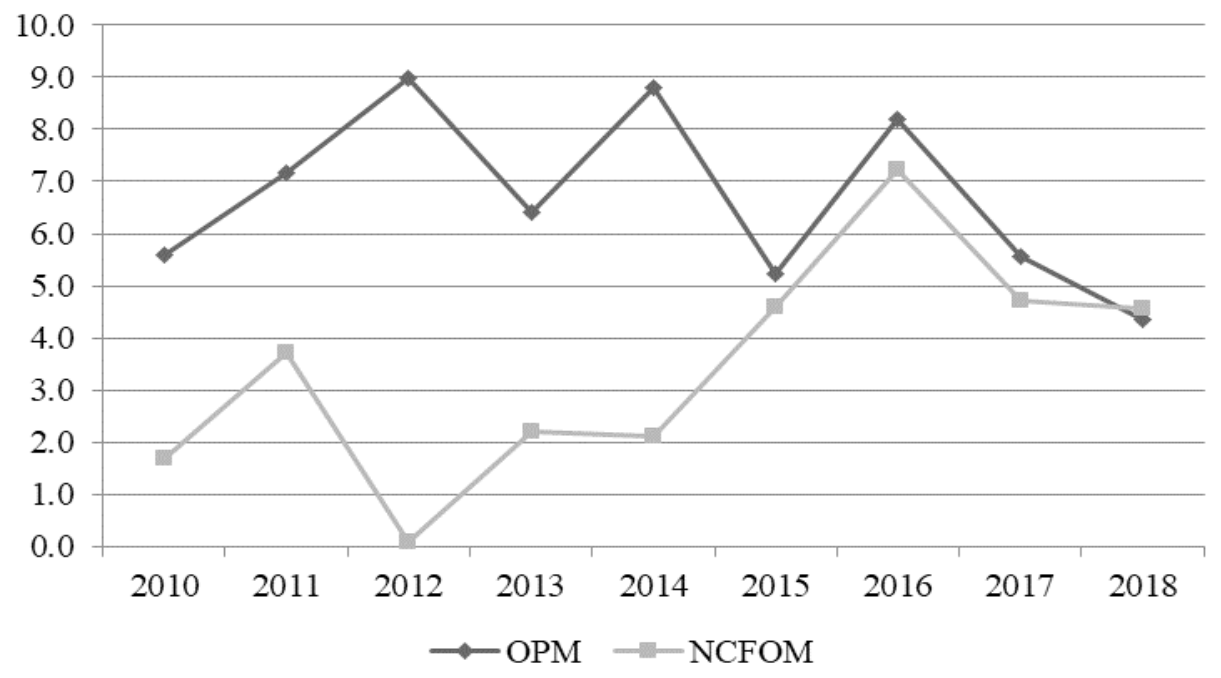

Source: Authors' calculation based on SBRA data

Note: OPM- Operating Profit Margin; NCFOM- Net Cash Flow Operating Margin

The trend of operating profit margin and cash flow operating margin is uniform in the period 2010-2011 and 2015-2018. After 2011, when the growth trend of operating profit margin and cash flow operating margin was recorded, a different trend was in 2012, when the operating profit margin continued to grow, and the cash flow margin decreased. The trend of operating profit margin and cash flow operating margin was again equal in 2015. In 2016 they increased compared to the previous year and then reduced in 2017 and 2018. The difference between operating profit margin and cash flow operating margin is the largest in 2012, while in period 2015-2018 median values of operating profit margin and cash flow operating margin are at the closest level, showing that the accruals is relatively stable in the last four years of the observed period. 
Accruals and net operating cash flows can be observed as determinants of operating profit. In that case, we can estimate the persistence of the operating profit separately estimating accruals and net operating cash flows. The following regression shows that accruals and net operating cash flows in the past period have different implications for the persistence of operating profit in the current period.

$$
O P M_{t+1}=0.929^{* * *} A C C_{t}+0.845^{* * *} \text { CFOM }_{t}+\varepsilon_{t+1}
$$

We evaluated panel regression with fixed and random effects. However, the Hausman test showed that the value of Chi-Sq. Statistic $=15.042$ with a $\mathrm{p}$-value of 0.001 and regression with fixed effects is more adequate. Therefore, we will only describe its results.

Table 2. Panel Regression Analysis

\begin{tabular}{|l|l|l|r|r|}
\hline \multicolumn{1}{|c|}{ Variable } & \multicolumn{2}{c|}{ Fixed Effects } & \multicolumn{2}{c|}{ Random Effects } \\
\hline & Coefficient & Prob. & Coefficient & Prob. \\
\hline C & -1.673 & 0.178 & -2.204 & 0.103 \\
\hline ACC $(-1)$ & 0.929 & 0.000 & 1.020 & 0.000 \\
\hline NCFOM(-1) & 0.845 & 0.000 & 0.946 & 0.000 \\
\hline Hausman test & 15.042 & 0.001 & & \\
\hline R-squared & 0.542 & & 0.435 & \\
\hline F-statistic & 7.81 & 0.000 & 207.514 & 0.000 \\
\hline
\end{tabular}

Source: Authors' calculation

Note: ACC-Accounting Accruals; NCFOM- Net Cash Flow Operating Margin

The value of determination coefficient $\left(\mathrm{R}^{2}\right)$ is $54.2 \%$ which means that this model explains so many variations. The remaining $45.8 \%$ of the variations remain unexplained by this model. The value of F-statistics and its p-value indicates that regression is statistically significant. The constant term is not statistically significant. Regression results show that operating profit that represents accrual is more persistent than operating profit backed by net operating cash flows, but with slight differences. These results can be explained by higher cash flows volatility in comparation to accruals volatility of selected Serbian agriculture enterprises. Our results indicate that for $1.00 \mathrm{RSD}$ of operating profit that represents accruals, 0.929 RSD will persist into next year's operating profit. For 1.00 RSD of operating profit that represents operating cash flows, 0.845 RSD will persist into next year's operating profit. Dechow and Schrand (2004) founded that earnings backed by cash flows are more persistent than earnings that represent accruals.

\section{Conclusions}

Earnings quality can be based on the one or a set of quality measures, but earnings persistence is earnings quality measures commonly used in the literature. In this paper, we assessed the earnings and cash flow persistence of selected Serbian agriculture enterprises' using panel autoregression and regression model for the period 2010-2018. 
For that purpose, we used operating profit margin and profit margin as accrual-based indicators and net cash flow operating margin, net cash flow investing margin, net cash flow financing margin and free cash flow margin as cash flow-based indicators. The contribution of this paper is the focus on the medium-sized enterprises that operate in the agriculture sector in Serbia and use of earnings and cash flow persistence indicators as earnings quality measures.

Serbian medium-sized agriculture enterprises notice an improvement in profitability flows in 2011, 2012, 2014, and 2016, measuring by medians of operating profit margin and profit margin. Unlike the earnings-based indicators' trend, the trend of observed cash flow-based indicators in the analysed period is unequal. The autoregression panel results indicate that operating profit is more persistent than net profit of analysed agriculture enterprises, but cash flow-based indicators have less persistence than operating profit. Accruals values are less persistent than operating profit and net profit but more persistent than free cash flow. A relationship between operating profit and net operating cash flow is relatively stable in the period 2015-2018 that is a good assumption for the operating profit quality and operating cash flow sustainability. Our regression results show more persistence of operating profit that represents accrual than the persistence of operating profit backed by net operating cash flows. It can be explained by higher cash flows volatility of Serbian agriculture enterprises than their accruals volatility. Future research can be done by estimating the earnings quality of Serbian enterprises using other quality measures or analysing enterprises that operate in some other economic sectors.

\section{Acknowledgements}

The authors acknowledge funding from the Ministry of Education, Science and Technological Development of the Republic of Serbia.

\section{Conflict of interests}

The authors declare no conflict of interest.

\section{References}

1. Aboody, D., Hughes, J., \& Liu, J. (2005). Earnings quality, insider trading, and cost of capital. Journal of Accounting Research, 43(5), 651-673. https://doi. org/10.1111/j.1475-679X.2005.00185.X

2. Boulton, T.J., Smart, S.B., \& Zutter, C.J. (2011). Earnings quality and international IPO underpricing. The Accounting Review, 86(2), 483-505. https://doi.org/10.2308/ accr.00000018

3. Dasmaran, V., \& Mulyani, S.D. (2019). The Effect of Environmental Accounting Implementation, Research and Development to Earnings Quality and Ethics as to Moderating Variables. Research Journal of Finance and Accounting, 10(24), 159167. https://doi.org/10.7176/RJFA/10-24-17 
4. Dechow, P.M., \& Schrand, C.M. (2004). Earnings quality, Monograph, Research Foundation of CFA Institute, 1-3927.

5. Dechow, P., Ge, W., \& Schrand, C. (2010). Understanding earnings quality: A review of the proxies, their determinants, and their consequences. Journal of accounting and economics, 50(2-3), 344-401. https://doi.org/10.1016/j.jacceco.2010.09.001

6. Demerjian, P.R., Lev, B., Lewis, M.F., \& McVay, S.E. (2013). Managerial ability and earnings quality. The Accounting Review, 88(2), 463-498. https://doi. org/10.2308/accr-50318

7. Đuričin, S., Beraha, I., \& Bodroža, D. (2018). Alternatives for existing the loss zone for medium-sized agricultural enterprises in the Republic of Serbia. Economics of Agriculture, 65(1), 391-411. https://doi.org/10.5937/ekoPolj1801391D

8. Đuričin, S., Stevanović, S., Ljumović, I., \& Simović, V. (2019). National network of medium enterprises in the Republic of Serbia. Belgrade: Institute of Economic Sciences, Retrieved from https://www.library.ien.bg.ac.rs/index.php/nmsp/article/ view/532/1059. (September 9, 2020).

9. Francis, J., Nanda, D., \& Olsson, P. (2008). Voluntary disclosure, earnings quality, and cost of capital. Journal of accounting research, 46(1), 53-99. https://doi. org/10.1111/j.1475-679X.2008.00267.X

10. Huq, A. M. (2016). Effect of earnings volatility on cost of debt: the case of Swedish limited companies. Dalarna University, Master's in Business Studies, Retrieved from https://www.diva-portal.org/smash/get/diva2:937817/FULLTEXT01.pdf (September 12, 2020).

11. Meeampol, S., Rodpetch, V., Srinammuang, P., \& Wongsorntham, A. (2013). Relationship between corporate governance and earnings quality: case study of listed companies in the Thailand Stock Exchange. In Active Citizenship by Knowledge Management \& Innovation: Proceedings of the Management, Knowledge and Learning International Conference 2013, 1345-1353.

12. Milić, D., Mijić, K., Jakšić, D. (2018). Opportunistic management behavior in reporting earnings of agricultural companies. Custos e agronegocio on line, 14(1), 125-142.

13. Mulford, C., \& Comiskey, E. (2005). Creative Cash Flow Reporting: Uncovering Sustainable Financial Performance, New Jersey: John Wiley \& Sons, Inc. Hoboken.

14. Nuris, D.M.R., \& Juliardi, D. (2017). The Effect of Auditor Switch Toward the Firm Value And Earning Persistance, Retrieved from https:/osf.io/preprints/ inarxiv/5mhu7/ (August 3, 2020).

15. Pagalung, G., \& Sudibdyo, B. (2018). The determinant factors of earnings quality and economic consequences. EKUITAS (Jurnal Ekonomi dan Keuangan), 16(1), 105-122. https://doi.org/10.24034/j25485024.y2012.v16.i1.150 
16. Perotti, P., \& Wagenhofer, A. (2014). Earnings quality measures and excess returns. Journal of Business Finance \& Accounting, 41(5-6), 545-571. https://doi. org/10.1111/jbfa.12071

17. SBRA - Serbian Business Registers Agency (2019). The Financial Statements Annual Bulletin, Retrieved from https:/www.apr.gov.rs/upload/documents/ Bilten\%202019.pdf (August 8, 2020).

18. SBRA - Serbian Business Registers Agency, The Register of Financial Statements, Retrieved from http://www.apr.gov.rs (February 25, 2020).

19. Srivastava, A. (2014). Why have measures of earnings quality changed over time? Journal of Accounting and Economics, 57(2-3), 196-217. https://doi. org/10.1016/j.jacceco.2014.04.001

20. Stevanović, S., \& Marinković, G. (2017). Impact of sales revenue quality on the earning quality: evidence from Serbian enterprises. In Thematic Monograph: Opportunities for inclusive and resilient growth, Belgrade: Institute of Economic Sciences, pp. 105-116. [in Serbian: Стевановић, С., \& Маринковић, Г. (2017). Утицај квалитета прихода од продаје на квалитет добитка: пример предузећа у Србији].

21. Stevanović, S., Belopavlović, G., \& Lazarević-Moravčević, M. (2013). Creative Cash Flow Reporting-the Motivation and Opportunities. Economic Analysis, 46(12), 28-39. 